METAgraphias: letra G de \#GOROROBA e outras abobrinhas v.2 n.4 dezembrol2017

Tendo uma experiência estética fastfood e ganhando likes no instagran sem sair de casa•Mateus Raynner André de Souza (mateusraynner@gmail.com)

\title{
Tendo uma experiência estética fastfood e ganhando likes no instagran sem sair de casa
}

Mateus Raynner André de Souza 
METAgraphias: letra G de \#GOROROBA e outras abobrinhas v.2 n.4 dezembrol2017

Tendo uma experiência estética fastfood e ganhando likes no instagran sem sair de casa•Mateus Raynner André de Souza (mateusraynner@gmail.com)

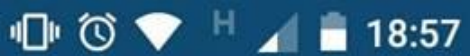
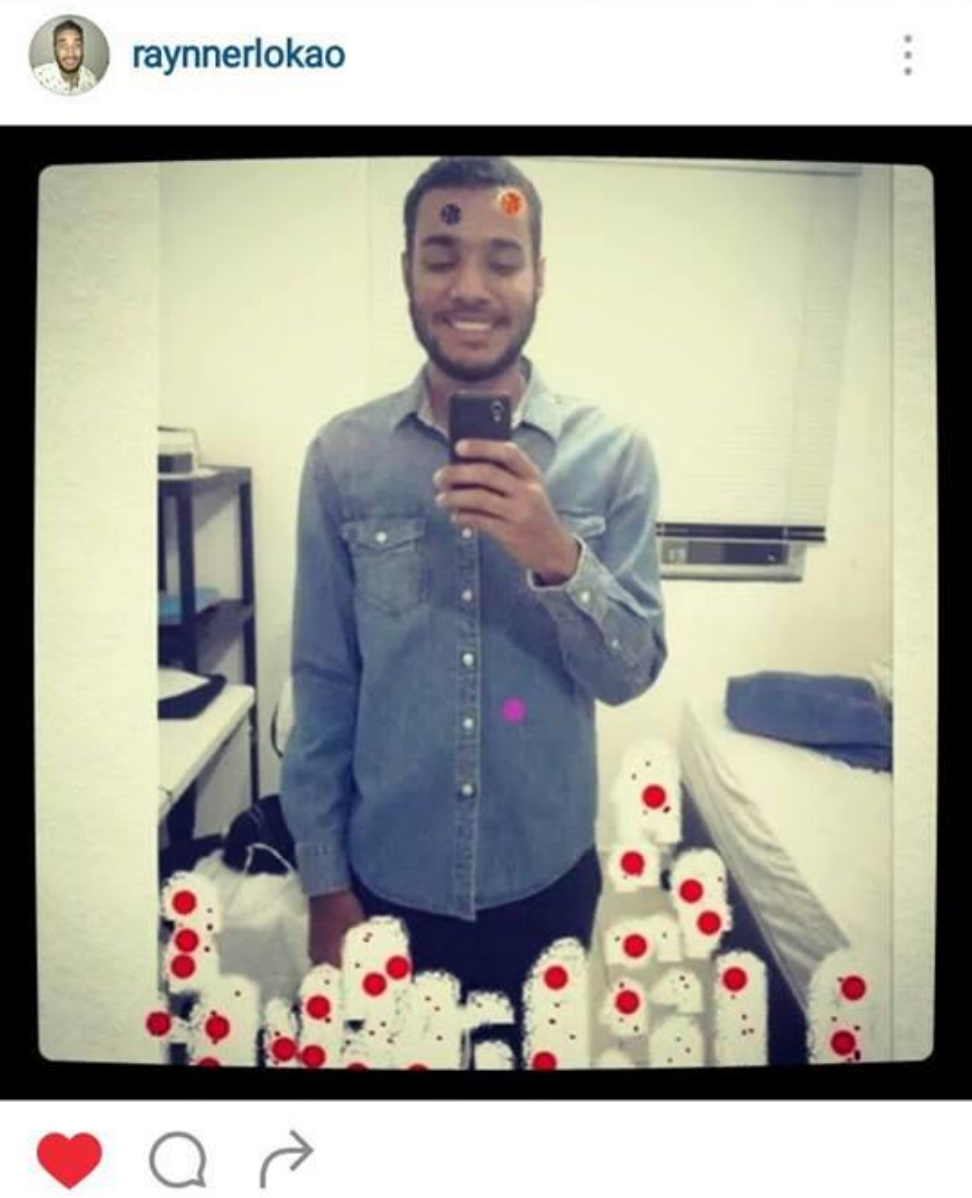

- 58 curtidas

raynnerlokao eu também tirei uma selfie na expo

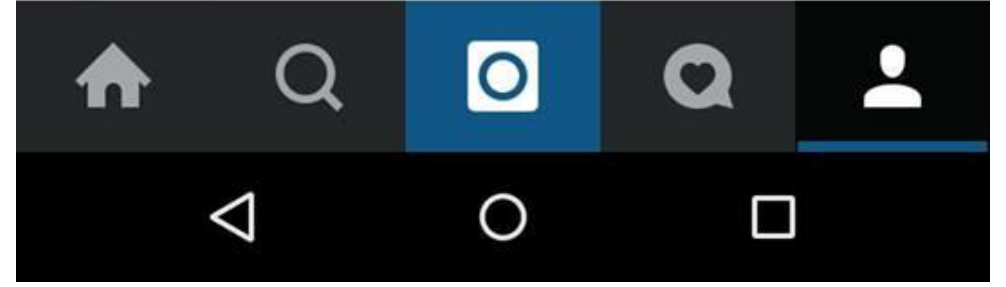

